\title{
Folate nutrition and growth in infancy
}

\author{
Y. MATOTH, I. ZEHAVI, E. TOPPER, AND T. KLEIN
}

Department of Paediatrics, Beilinson Medical Centre, Petah Tiqva, and the Sackler School of Medicine, Tel Aviv University, Israel

SUMMARY The effect of suboptimal folate nutrition on the growing infant was studied in a population of infants fed a diet based on boiled, pasteurised cows' milk. One group of infants received a daily supplement of $1 \mathrm{mg}$ folic acid from age 2 months, while the other group received a placebo. The infants were seen at bimonthly intervals. In the supplemented group the red cell folate level had increased to twice its pretreatment value by 4 months, and remained at this high level to the end of the first year. $\mathrm{Hb}$ concentration and incidence of anaemia were similar in both groups. The incidence of infection in the two groups did not differ. Weights and lengths attained at 6 months, and the rate of gain from 2 to 6 months were higher in infants whose folate levels were above the median value than in those below it. In the second half of the first year the differences between the two groups were no longer evident.

The classical description by Zuelzer and Ogden (1946) of folate-responsive megaloblastic anaemia of infancy drew attention to the fact that young babies were a group particularly at risk for folate deficiency. Interest subsequently focused largely on megaloblastic anaemia as a manifestation of folate deficiency. Other, less obvious effects of suboptimal folate nutrition are less well documented.

The present study was initiated to detect any effects of folate undernutrition on the growing infant. The study was facilitated by the practice of infant feeding current in Israel, which is based on the use of boiled pasteurised cows' milk. Milk treated in this manner has been shown to be a poor source of folate. Furthermore, infants fed such a diet tend to have low blood-folate levels (Matoth et al., 1965). It was therefore of interest to investigate whether a population of apparently healthy infants fed the standard diet and presumed to be suboptimally provided with folate was in any way inferior to a folate-replete group, created by the daily administration of large doses of folic acid.

\section{Study population and methods}

The study was carried out in Rosh Ha-Ayin in central

Department of Paediatrics, Beilinson Medical Centre, Petah Tiqva, Israel

$Y$. MATOTH, professor of paediatrics

I. ZEHAVI, paediatrician

E. TOPPER, paediatrician

T. KLFIN, microbiologist
Israel. This community was chosen because it is uniformly inhabited by Yemenite Jews who immigrated to Israel in 1949-50 and therefore represent a homogeneous population with respect to ethnic and cultural backgrounds as well as to socioeconomic status. The Rosh Ha-Ayin area is served by two child health clinics. Each infant attending clinic A received a daily supplement of $1 \mathrm{mg}$ folic acid in the form of a specially prepared tablet, while those attending clinic B received a placebo. Supplementation was started at 2 months and the infants were seen at regular bimonthly intervals from age 2 months to one year. The red cell folate levels, $\mathrm{Hb}$ concentrations, weights and lengths were determined at each visit. At each clinic the infants were weighed and measured by the same experienced trained nurses. The incidence of infection was monitored and recorded.

100 term infants whose birthweights were $>2 \cdot 5$ $\mathrm{kg}$ were studied. The male:female ratio was 53:47 in clinic A and 49:51 in clinic B. The attendance was practically complete. It was therefore possible to terminate the study when the first 53 infants in clinic $A$ and the first 60 in clinic $B$ had reached age one year. The mothers did not know which infant was receiving the active material. Each was informed of the potentially beneficial effects of folic acid, and her consent to enrolling the infant in the trial and her co-operation were obtained.

Folate in whole blood was determined with a micromethod using $0.1 \mathrm{ml}$ skin prick blood. The procedure of Cooperman (1967) was followed. The 
method has been in routine use in our laboratory for the last 10 years and has given consistent results. The folate values obtained with this method are higher than those recorded in our earlier publications (Matoth et al., 1965). Red cell folate was calculated by multiplying the values found in whole blood by $100 \div$ haematocrit.

\section{Results}

Red cell folate values, determined at bimonthly intervals from 2 months to one year of age in the infants supplemented with folate (clinic A) and in the unsupplemented group (clinic B), are shown in Table 1. The initial values, obtained at 2 months before supplementation was begun, were similar in both groups. Thereafter, folate values in babies from clinic B remained low at 4 and 6 months and showed a moderate increase subsequently. In contrast, supplementation with folic acid (clinic A) more than doubled the red cell folate at 4 months, and this high level was maintained throughout the first year.

It can be seen from Table 1 that the increase in folate had no effect on $\mathrm{Hb}$ concentration, which remained very similar in the two groups throughout the period of observation. The mean values in both groups tended to decrease in the second half of the first year. This was due to the occurrence of anaemia. 15 infants in clinic $\mathrm{A}$ and 11 in clinic $\mathrm{B}$ had $\mathrm{Hb}<10$ $\mathrm{g} / \mathrm{dl}$ when they were between 8 and 12 months; the anaemia was caused by iron deficiency. They were given treatment with iron and excluded from further study.

Of 357 episodes of acute gastroenteritis and respiratory infection recorded during the period of observation, 164 were in babies from clinic A and 193 from those at clinic B. The difference was, however, not significant.

In the group of infants supplemented with folic acid from age 2 months, the weights and lengths attained at 4 and 6 months were significantly higher than in the unsupplemented group. The difference was no longer evident in the second half of the first year (Table 1). The relation of changes in weight and length to the folate status was further evaluated by combining the babies from both clinics and comparing, for each age group, infants whose folate levels were above the median value with those whose

Table 1 Red cell folate levels, haemoglobin concentrations, weights, and lengths in infants supplemented (clinic A) and unsupplemented (clinic B) with folic acid, mean $\pm S E$

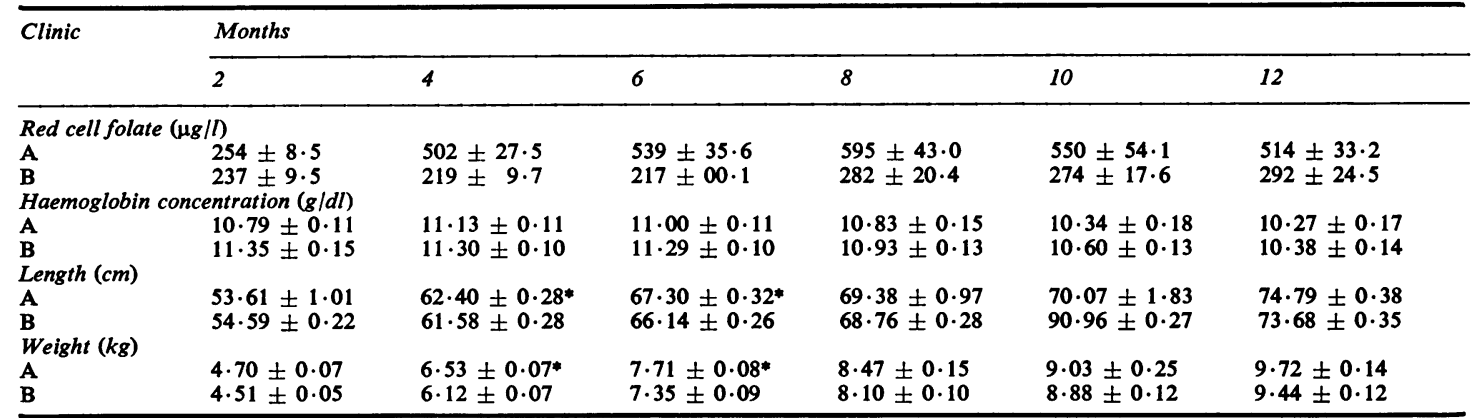

*Significantly higher than corresponding value in clinic B $(\mathrm{P}<0.05)$.

Table 2 Weights and lengths of infants with high and low folate levels, mean $\pm S E$

\begin{tabular}{|c|c|c|c|c|c|c|}
\hline Folate level & $\begin{array}{l}\text { Months } \\
2\end{array}$ & 4 & 6 & 8 & 10 & 12 \\
\hline \multicolumn{7}{|c|}{ Red cell folate $(\mu \mathrm{g} / l)$} \\
\hline High & $310 \pm 8$ & $527 \pm 25$ & $557 \pm 31$ & $658 \pm 37$ & $551 \pm 38$ & $526 \pm 25$ \\
\hline $\begin{array}{l}\text { Low } \\
\text { Weight }(k g)\end{array}$ & $183 \pm 4$ & $186 \pm 5$ & $179 \pm 6$ & $200 \pm 8$ & $191 \pm 9$ & $208 \pm 9$ \\
\hline $\begin{array}{l}\text { High } \\
\text { Low } \\
\text { Length }(\mathrm{cm})\end{array}$ & $\begin{array}{l}4.699 \pm 0.61 \\
4.518 \pm 0.65\end{array}$ & $\begin{array}{l}6.549 \pm 0.07^{*} \\
6.096 \pm 0.0\end{array}$ & $\begin{array}{l}7 \cdot 789 \pm 0.09^{*} \\
7 \cdot 240 \pm 0.08\end{array}$ & $\begin{array}{l}8.489 \pm 0.15^{*} \\
8.069 \pm 0.10\end{array}$ & $\begin{array}{l}9.052 \pm 0.19 \\
8.817 \pm 0.13\end{array}$ & $\begin{array}{l}9.803 \pm 0.13 \\
9.377 \pm 0.13\end{array}$ \\
\hline $\begin{array}{l}\text { High } \\
\text { Low }\end{array}$ & $\begin{array}{l}53.31 \pm 0.98 \\
54.95 \pm 0.24\end{array}$ & $\begin{array}{l}62.39 \pm 0.27 \\
61.66 \pm 0.29\end{array}$ & $\begin{array}{l}67.29 \pm 0.31^{*} \\
66.02 \pm 0.26\end{array}$ & $\begin{array}{l}69.42 \pm 0.97 \\
68.69 \pm 0.29\end{array}$ & $\begin{array}{l}70.55 \pm 1.24 \\
70.74 \pm 0.53\end{array}$ & $\begin{array}{l}74 \cdot 74 \pm 0.3 \\
73 \cdot 78 \pm 0.38\end{array}$ \\
\hline
\end{tabular}

High and low folate $=$ folate levels above and below median.

*Significantly higher than corresponding 'low folate' value $(P<0.05)$. 
Table 3 Changes in weights and lengths from 2 to 6 months in infants with high or low folate levels, mean $\pm S E$

\begin{tabular}{|c|c|c|c|c|}
\hline \multirow[t]{2}{*}{ Folate level } & \multicolumn{2}{|l|}{ At 6 months } & \multicolumn{2}{|c|}{ Increment from 2 to 6 months } \\
\hline & Weight (kg) & Length $(\mathrm{cm})$ & Weight (kg) & Length $(\mathrm{cm})$ \\
\hline $\begin{array}{l}\text { High } \\
\text { Low } \\
\text { P }\end{array}$ & $\begin{array}{l}7.789 \pm 0.09 \\
7.240 \pm 0.08 \\
<0.001\end{array}$ & $\begin{array}{l}67.293 \pm 0.310 \\
66.02 \pm 0.265 \\
0.002\end{array}$ & $\begin{array}{l}3 \cdot 134 \pm 0.077 \\
2.743 \pm 0.070 \\
<0.001\end{array}$ & $\begin{array}{l}13.326 \pm 0.866 \\
11.472 \pm 0.244 \\
0.042\end{array}$ \\
\hline
\end{tabular}

High and low folate $=$ folate levels above and below the median value at 6 months.

levels were below it (Tables 2 and 3). Weights and lengths at 6 months were significantly higher in the high folate than in the low folate group. In the former, weights were higher also at 4 and 8 months. As shown in Table 3, the rate of gain in weight and length from 2 to 6 months, calculated from individual increments, was significantly higher in the high folate group.

\section{Discussion}

It is evident from our data that growth can be enhanced in apparently healthy infants by providing them with an abundant supply of folic acid. Conversely, it may be concluded that a shortage of folate can be a limiting factor to growth. This is not surprising, as it is well known that folates are essential for DNA and RNA synthesis. Accordingly, the folate requirements for cell proliferation in the rapidly growing organism are very high. The fetus is well endowed with folate at birth. Soon after, the blood folate level decreases and reaches a low point at 6 to 8 weeks (Matoth et al., 1964a). From that age on the infant depends entirely on diet for its folate needs. The age group 2 to 6 months is, therefore, a critical period. On the one hand, this is a period characterised by a high growth rate and, accordingly, maximal folate requirements. If, on the other hand, intake is marginal, as is the case in our population, shortage of folate may affect growth. In the second half of the first year, as growth slows down, there is a relative decrease in folate requirements. At the same time intake is increased by the introduction of folate-rich foods. As a result, the infants achieve a better folate balance and catch up in weight and length with their folate-replete fellows.

There are few reports dealing with the effects of folate deficiency on growth. The administration of $50 \mu \mathrm{g}$ folic acid per day to low birthweight infants did not increase their weight at 6 months (Kendall et al., 1974). More recently, Gandy and Jacobson (1977a) found in infants with erythroblastosis fetalis a tendency to low serum-folate, which persisted throughout the first year of life. In these infants there was a strong correlation between low serum-folate and the rate of weight gain. It is of interest that supplements of $2 \cdot 5-5 \mathrm{mg}$ folic acid given to erythroblastotic infants resulted in an increase in the rate of weight gain at 4 months, compared with nonsupplemented erythroblastotic controls (Gandy and Jacobson, 1977b).

In the present study, folate shortage of a degree sufficient to cause a measurable deceleration of growth did not affect $\mathrm{Hb}$ concentration. The incidence of anaemia was similar in the folate-rich and folate-poor groups. Anaemia, when present, bore the mark of iron deficiency. Furthermore, it occurred late in the first year, at a time when folate shortage, as shown by its effect on growth, was no longer evident. The high incidence ( 26 cases) of anaemia in our material reflects the prevalence of iron deficiency in babies in Israel.

In a previous study (Matoth et al., 1964b), hospitalised infants with a wide range of $\mathrm{Hb}$ and folate levels showed no correlation between these two variables. It appears therefore that, even in a population of infants with relative shortage of folate, iron deficiency is the dominant factor in nutritional anaemia, whereas folate deficiency of a degree of severity or duration necessary to produce anaemia is uncommon.

\section{References}

Cooperman, J. M. (1967). Microbiological assay of serum and whole-blood folic acid activity. American Journal of Clinical Nutrition, 20, 1015-1024.

Gandy, G., and Jacobson, W. (1977a). Influence of folic acid on birthweight and growth of the erythroblastotic infant. II. Growth during the first year. Archives of Disease in Childhood, 52, 7-15.

Gandy, G., and Jacobson, W. (1977b). Influence of folic acid on birthweight and growth of the erythroblastotic infant. III. Effect of folic acid supplementation. Archives of Disease in Childhood, 52, 16-21.

Kendall, A. C., Jones, E. E., Wilson, C. I. D., Shinton, K. N., and Elwood, P. C. (1974). Folic acid in low birthweight infants. Archives of Disease in Childhood, 49, 736-738.

Matoth, Y., Pinkas, A., Zamir, R., Mooallem, F., and Grossowicz, N. (1964a). Studies on folic acid in infancy. I. Blood levels of folic and folinic acid in healthy infants. Pediatrics, 33, 507-511. 
Matoth, Y., Zamir, R., Bar-Shani, S., and Grossowicz, N. (1964b). Studies on folic acid in infancy. II. Folic and folinic acid blood levels in infants with diarrhea, malnutrition, and infection. Pediatrics, 33, 694-699.

Matoth, Y., Pinkas, A., and Sroka, Ch. (1965). Studies on folic acid in infancy. III. Folates in breast fed infants and their mothers. American Journal of Clinical Nutrition, 16, 356-359.

Zuelzer, W. W., and Ogden, F. N. (1946). Megaloblastic anemia in infancy, a common syndrome responding specifically to folic acid therapy. American Journal of Diseases of Children, 71, 211-243.

Correspondence to Dr Y. Matoth, Department of Paediatrics, Beilinson Medical Centre, Petah Tiqva, Israel.

Received 9 January 1979

The following articles will appear in future issues of this journal:

Human growth hormone (UK). R. D. G. Milner.

A prospective study of 18 infants of chronic HBsAg mothers. F. Mollica, S. Musumeci, S. Rugolo, and T. Mattina.

Virus infections in children with acute lymphoblastic leukaemia. A. W. Craft, M. M. Reid, P. S. Gardner, E. Jackson, J. Kernahan, J. McQuillin, T. C. Noble, and W. Walker.

Oral fat loading test: a reliable procedure for the study of fat malabsorption in children. A. Jonas, $S$. Weiser, P. Segal, and D. Katznelson.

Confirmation of gestational age by external physical characteristics (total maturity score). J. I. Cater.

Takayasu's arteritis as a differential diagnosis of systemic juvenile chronic arthritis. E. Rossor. 